\title{
СЕМАНТИКА И СОЧЕТАЕМОСТЬ ПОЛЬСКИХ И РУССКИХ ИМЕН ПРИЛАГАТЕЛЬНЫХ С СУФФИКСОМ -LIW- /-ЛИВ-
}

\author{
SEMANTICS AND VALENCE OF POLISH AND RUSSIAN \\ ADJECTIVES WITH THE SUFFIX -LIW-/-ЛИВ-
}

\author{
КАТАЖИНА КУЛИГОВСКА
}

\begin{abstract}
The author analyzes the different shades of meaning and the semantic valency of Polish and Russian adjectival derivatives with the suffix -liw-/-ıub-. The words that are studied here exhibit an anthropocentric orientation as they principally describe natural human inclinations and collocate with personal nouns. Semantically impersonal adjectives are sparse among the analyzed lexemes in both languages.
\end{abstract}

Katarzyna Kuligowska, Uniwersytet im. Adama Mickiewicza w Poznaniu, Poznań - Polska.

Суффикс -liw- считают расширением морфемы -iw-, которое возникло путем морфологической абсорбции -l-1. Однако Я. Лось обращает внимание на факт, что таких имен, в которых могла бы наступить упомянутая абсорбция (напр. myśliwy < myśl, truchliwy < truchty), в славянских языках очень немного, а таких, которые могли бы образоваться от причастий на -t-, в польском языке почти нет (lękliwy, brzydliwy, zjadliwy), а в других славянских языках они очень редки².

В современных польских словарях зафиксировано 200 адъективных дериватов с суффиксом -liw-. Словари современного русского языка содержат 201 прилагательное с морфемой -лив-. Из списка собранных единиц для структурно-семантического анализа были исключены слова устаревшие и редко появляющиеся в современном употреблении, напр. łyskliwy, ofukliwy, słotliwy, рассудливый, щзапливый, полохливый, а также дериваты, образованные другими, чем суффиксальный, способами, т. е. префиксальным или конфиксальным способом, напр.: uciażliwy, zjadliwy, беззаботливый, непоседливыи, несуетливыи, и путем словосложения, напр.: жаровыносливый, малопонятливый. В сумме анализу подверглось 155 польских и 168 русских прилагательных с упомянутым суффиксом.

${ }^{1}$ H. K u r k o w s k a, Budowa stowotwórcza przymiotników polskich, Wrocław 1953, c. 23.

2 J. Ł o ś, Gramatyka polska, cz. II: Stowotwórstwo, Lwów-Warszawa-Kraków 1925, c. 22. 
Прилагательные с суффиксом -liw-/-лиb- мотивируются как глагольными, так и именными основами. В анализируемом материале к отглагольным относится 96 польских и 96 русских дериватов, т. е. $62 \%$ польских и $57 \%$ русских суффиксальных образований. Некоторые из польских и русских отглагольных дериватов характеризует добавочная мотивация именем существительным. Она свойственна прежде всего тем словам, которые называют признак, связанный с издаваемым звуком, выраженным мотивирующим существительным, напр.: grzechotliwy (< grzechotać, grzechot), szczebiotliwy (< szczebiotać, szczebiot), świergotliwy (< świergotać, świergot); крикливый (< кричать, крик), пискливый (< пищзать, писк), хохотливый (< хохотать, хохот).

X. Курковска констатирует, что отглагольные прилагательные имеют значение производителя действия, названного мотивирующей основой ${ }^{3}$. Она употребляет по отношению к ним термин „адъективные nomina agentis" и подчеркивает, что по значению они сближаются с действительными причастиями, напр. dolegliwy - 'dolegający', migotliwy - 'migający', szkodliwy - 'szkodzący', но отличаются от них независимостью от категории времени и потенциальным оттенком значения, т. е. указывают не на постоянное действие, а на постоянное предрасположение к определенному действию4.

Дериваты, происходящие от глаголов, имеют следующее словообразовательное значение: „склонный к действию, названному мотивирующим словом"5: frasobliwy, kłótliwy, lękliwy, pamiętliwy; бранливый, дреммивый, пакостливый, прожорливый. Р. Гжегорчикова относит такие образования к диспозищионным прилагательным (przymiotniki skłonnościowe) $)^{6}$. Она обращает также внимание на возможное побочное значение отглагольных дериватов данного разряда, т. е. „выражающий состояние, названное мотивирующей основой"7. Такую семантику обсуждаемые прилагательные приобретают в сочетаниях типа frasobliwy wyraz twarzy, бранчливыи голос, в которых они теряют свой диспозиционный характер. Среди диспозиционных прилагательных в особый разряд выделяются прилагательные пассивного характера, обладающие значением „склонный подвергаться дейсвтию, названному мотивирующим глаголом", напр. pobudliwy, obraźliwy8, брезгливый, страшливый. К ним по значению близко стоят слова типа barwliwy, krzepliwy, kurczliwy, tamliwy, nasiakliwy, rozprężliwy, хотя Р. Гжегорчикова выделяет их

\footnotetext{
${ }^{3}$ Н. K u r k o w s k a, указ. соч., с. 1-11.

4 Там же, с. 38.

${ }_{5}$ Русская грамматика, под ред. Н.Ю. Шведовой, т. 1, Москва 1980, с. 296.

${ }^{6}$ R. G r z e g o r c z y k o w a, Zarys stowotwórstwa polskiego, Warszawa 1981, c. 66.

7 Там же.

8 Там же.
} 
в особый разряд и называет потенциальными прилагательными со структурой „такой, который может быть объектом действия". Нельзя не заметить, что среди собранных русских прилагательных с суффиксом -лиъ- нет слов с таким оттенком значения, зато в польском материале они представлены числом 15 единиц и в большинстве случаев относятся к специальным пластам лексики, таким как техническая терминология (ściśliwy, topliwy) или книжная лексика (znikliwy - 'mający tendencję do znikania, do stawania się niwidocznym, do dematerializowania się').

Имена существительные мотивируют 54 польских и 69 русских дериватов, т. е. соответственно около 35\% и 41\% всех анализируемых прилагательных. Отсубстантивные адъективы характеризуются следующими словообразовательными значениями: „характеризующийся тем, что названо мотивирующим словом” и „имеющий свойства того, что названо мотивирующим словом"10. Первым из вышеуказанных значений обладают прилагательные, характеризующиеся различными семантическими отношениями между словообразовательной основой и дериватом. Мотивирующая основа может называть эмоции, напр. bojaźliwy, rozpaczliwy, strachliwy, гневливыи, жалостливыи, стыдливыи, элемент поведения, напр.: psotliwy, ruchliwy, troskliwy, изворотливый, прихотмивый, суматошливый, атмосферные явления, напр. burzliwy, mgliwy, bъюжливый, моросливый, снежливый, физический или психический признак, напр. chrypliwy, chutliwy, одышливый, талантливый, издаваемый звук, напр. bekliwy, betkotliwy, brzękliwy, chrypliwy, chrobotliwy, jazgotliwy, jękliwy, rechotliwy, skrzekliwy, warkotliwy и др. Дериваты, обладающие вторым значением, так называемые симилятивные прилагательные, преобладают в русском материале, ср., напр.: дурачливыи (< дурак), жлобливый, забиячливый, нерячиливый, плутливый, пройдочливый, ребячливый, сиротлиbый. К данной группе можно отнести лишь три польских прилагательных: gburliwy, mrukliwy, tchórzliwy.

Отадъектиные прилагательные с суффиксом -liw-/-лиb- составляют немногочисленную группу слов (5 польских и 3 русских), которые называют „различные оттенки признака, выраженного мотивирующим прилагательным"11: częstotliwy, rzewliwy, straszliwy, szczodrobliwy, świątobliwy, гадливый, горделивый, особливый.

А. Белянин разделяет класс качественных прилагательных на эмпирийные и рациональные ${ }^{12}$. K эмпирийным прилагательным он от-

9 Там же, с. 67.

10 Русская грамматика, указ. соч., с. 290.

11 Там же, с. 302.

$12 \mathrm{~A}$. B i e 1 a n i n, Łączliwość przymiotników z rzeczownikami w języku polskim i rosyjskim, Rzeszów 1989, c. 98-100. 
носит те слова, которые выражают признаки, воспринимаемые органами чувств, т. е. признаки, воспринимаемые зрительно, осязательно, на слух, на вкус и т. д. ${ }^{13}$ Рациональными он называет прилагательные, которые выражают признаки, являющиеся выводами, сделанными на основании оценки признаков, воспринятых органами чувств, т. е. слова, указывающие на физическое состояние, слова, называющие психические и духовные свойства, слова, характеризующие материальное или социальное положение, и т. п. ${ }^{14}$

Распределяя собранный материал по группам, предложенным Беляниным, можно заметить, что среди дериватов на -liw-/-лив- самую многочисленную группу составляют рациональные имена прилагательные, которые указывают на психические, моральные и духовные признаки (132 русских и 74 польских прилагательных), напр.: burkliwy, milkliwy, pamiętliwy, powściagliwy; боязливый, гневливый, молчаливый, обиходливый, похотливый, слезливый. Единичные дериваты характеризуют физическое состояние, напр.: выносливый, плодливый, простудливый, и социальное или жизненное положение: szczéśliwy, задачливый, незадачмивый, сиротливый, удачливый.

Менее многочисленны эмпирийные прилагательные (66 польских и 38 русских), среди которых можно выделить дериваты, указывающие на зрительно воспринимаемые признаки, напр.: czerwliwy, migotliwy, połyskliwy, ruchliwy, брыкливый, затейливый, неряшливый, причудливый, сопливый, спотыкливый, в том числе и признаки, связанные с атмосферными явлениями, напр.: burzliwy, mgliwy, дождливый, засушливый, моросмивыи, снежливыи; дериваты, называющие признаки, воспринимаемые на слух, напр.: chrobotliwy, jazgotliwy, klekotlliwy, zgrzytliwy, гнусливыи, пискливый, хрипливыг; дериваты, передающие признаки, воспринимаемые осязательно: lepliwy, łaskotliwy, потливый, ухвытливыи, или обонянием: smrodliwy.

Слова, указывающие на признаки, воспринимаемые органами чувств, А. Нагурко называет перцептивными прилагательными, обращая внимание на факт, что только они могут служить основой метафорических переносов, что объясняется связью метафоры с чувственным восприятием ${ }^{15}$. Анализируемый материал подтверждает эту констатацию, так как метафорическим значением обладают такие прилагательные, как: burzliwy ('obfitujący w niezwykłe wydarzenia', напр. burzliwe dzieje), chwytliwy ('taki, który łatwo znajduje oddźwięk, szybko się przyjmuje, trafia do przekonania', напр. chwytliwy slogan), крикливый ('кричащий, вы-

13 Там же, с. 98-99.

14 Там же, с. 99-100.

15 A. N a g ó r k o, Zagadnienia derywacji przymiotników, Warszawa 1987, c. 10. 
чурный', напр. крикливый наряд), уродииый ('ненормальный, нелепый до безобразия', напр. уродливый вкус).

Е.М. Вольф подчеркивает, что „прилагательные принадлежат к предикатным словам, они не указывают на предметы, а приписуют им признаки"16. Таким образом, „прилагательные как предикатные слова лишены денотации и референции [...], они имеют сигнификат, но не имеют денотата" 17 . В связи с этим следует сказать, что имена прилагательные составляют семантически несамостоятельный класс слов, их семантика в большой степени обусловлена семантикой определяемых ими существительных и, как замечает Вольф, „на значение прилагательного всегда проецируется значение носителя признака"18.

В связи с вышесказанным для полноты исследования считаем целесообразным провести семантический анализ сочетаний, в которые вступают анализируемые суффиксальные прилагательные на -liw-/-лив-, и представить валентность этих прилагательных.

В лингвистической литературе определение понятия валентности вызывает разногласия ${ }^{19}$. Белянин контстатирует, что „валентностью называется потенциальная возможность употребления слов друг с другом, заложенная в самой системе языка” 20 , в то время как „сочетаемость слов - это реализованная способность языковых единиц к соединению в речи, которая проявляется в определенных условиях (речевая ситуация, контекст) и зависит от многих экстралингвистических и лингвистических факторов" 21.

Учитывая разряды существительных, с которыми сочетаются прилагательные на -liw-/-ıиb-, анализируемые дериваты можно разделить на следующие группы:

а) моносемичные прилагательные, которые в силу своего значения (значение склонности к действию, которое может выполняться лишь человеком) сочетаются только с существительными личной семантики, напр.: dociekliwy, gadatliwy, kochliwy, milkliwy, ustępliwy, życzliwy; болтливый, обычливый, понятливый, прислужливый, ропотливый, угадливый;

б) полисемичные прилагательные, в одном значении сочетающиеся с существительными личной семантики, а в другом значении с существительными, называющими:

16 Е.М. В о л ь ф, Грамматика и семантика прилагательного, Москва 1978, с. 6.

17 Там же.

18 Там же, с. 7.

${ }^{19}$ См. А. В i e 1 a n i n, указ. соч.; T. S e r e d y n i e c k a, Rosyjsko-polskie studium konfrontatywne łączliwości leksemów przymiotnikowych, Wrocław 1981.

20 Там же, с. 51.

21 Там же. 
- действия и качества, напр.: cnotliwa panienka - cnotliwe myśli, taskotliwe dziecko - łaskotliwe dotknięcie, kłamliwy człowiek - kłamliwa plotka, troskliwa matka - troskliwa opieka, гнусливый старик - гнусливое пение, торопливые посетители - торопливые таги, хвастливый человек - хвастливый тон, шаловливый ребенок - шаловливый взгляд;

- конкретные предметы и вещества, а также продукты человеческой деятельности, напр.: napastliwy krytyk - napastliwy artykut, chwytliwy umyst - chwytliwy slogan, krzykliwy dzieciak - krzykliwy krawat, ruchliwe pociechy - ruchliwy przejazd, причудливый старик - причудливый наряд, талантливый карикатурист - талантливый фильм, податливый бригадир - податливый воск, поворотливая хозяйка - поворотливая лодка;

- часть тела человека, напр.: уродливый мужчина - уродливое лицио, потливыи ребенок - потливые руки, костливая женщина - костливая рука.

В отдельную группу выделяются прилагательные, предрасположенные сочетаться с существительными личной семантики и дополнительно с существительными со значением времени, ср.: суматошливые дни, счастливое детство, тоскливая осень; или со значением объектов животного и растительного мира, ср.: kaśliwe muchy, lękliwa mysz, płochliwy źrebak, спотыкливая лотадь, боязливый заяи, блудливая кошка, выносливое дерево, плодливый хрен.

Стоит обратить внимание на ряд польских прилагательных, которые непосредственно не характеризуют лиц, но дают оценку человеческому поведению и качествам, напр.: chorobliwy (oszczędność, nieśmiałość, wstyd, apetyt), pieszczotliwy (słowa, nazwy, zdrobnienie, musnięcie), uszczypliwy (uwaga, komentarz, przytyk), wzgardliwy (uśmiech, milczenie, grymas, obojętnośc).

С неличными существительными сочетается лишь 15\% польских и 10\% русских прилагательных на -liw-/-лиb-. Среди них выделются прилагательные, характеризующие атмосферные явления и вступающие в отношения с существительными временной и/или локативной семантики, ср.: непогодливый вечер - непогодливое море, засушливый год - засушиивая зона, дождливая пора, моросливое утро.

Небольшим количеством представлены прилагательные, валентность которых ограничена вещественными или предметными существительными, напр.: ciagliwy metal, kurczliwa folia, krzepliwa krew, tupliwe drewno, przesiąliwa bibuła, rozciagliwa taśma; въедливые испарения, удушливый газ. Немногочисленные прилагательные указывают на признаки, свойственные лишь животным, и образуют атрибутивные словосочетания с существительными-анимализмами, ср.: szczekliwy pies, wierzgliwy kой, ройливые пчелы, бодливый козел, удойливая корова.

Интересно отметить, что лишь единичные прилагательные характеризует сочетаемость, ограниченная несколькими существительны- 
ми, напр.: chodliwy (towar, artykuty), dotkliwy (ból, strata, kara), а только один дериват можно отнести к моновалентным: podchwytliwy, употребляемый в сочетании podchwytliwe pytanie, хотя в корпусе польского языка можно найти и другие, нетипичные сочетания данного слова с существительными, напр.: podchwytliwe zadania, oferty biur, tematy, testy, zasady ortograficzne22.

Сравнительный анализ польских и русских прилагательных с формантом -liw-/-лиb- показал, что полная эквивалентность, как формальная, так и семантическая, характеризует 17 пар дериватов $(10 \%$ всех анализируемых прилагательных), напр.: гневливыи - gniewliwy, пискливый - piskliwy, кокетливыи - kokietliwy. Эквивалентность по значению и тождество суффикса наблюдаются в 27 парах (ок. 17\% всех собранных единиц) анализируемых прилагательных, напр.: psotliwy - проказмивый, zrzędliwy - брюзгливый, taskotliwy - щекотливый, szczekliwy - брехливый. Остальные имена прилагательные имеют в качестве эквивалентов в сравниваемом языке дериваты другой словообразовательной структуры, напр.: łamliwy - ломкий, nasiąliwy / wsiakliwy - влагоемкий, watpliwy - сомнительный, zająkliwy - косноязычный; выносливый - wytrzymały, глуммивый - szyderczy, затейливый - wymyślny. Нередко эквивалентом прилагательного с суффиксом -liw-/-лиb- в другом языке можно считать причастие, напр.: chichotliwy - хихикающий, сzерliwy - цееляющийся, grzechotliwy - грохочущий, terkotliwy - тарахтящий; молчаливый - milczacy, pопотливыи - utyskијасу, удуиливыи - duszacy, участливый - wspótczuја̨су.

В заключение следует сказать, что суффикс -liw- /-лиb- - это словообразовательное средство, проявляющее наибольшую продуктивность в области деривации прилагательных с антропоцентричной ориентацией. Имена со значением признака, приписываемого неличным объектам действительности, в обоих языках занимают периферийное место в категории исследуемых дериватов. Различия между польскими и русскими прилагательными на -liw-/-ıиb- сводятся к количественным характеристикам отдельных разрядов собранных слов: в русском языке более так называемых симилятивных прилагательных, типа забиячливый, дурачливый, и названий признаков, относящихся к атмосферным явлениям, напр. засушливый, дождливый; в польском, в свою очередь, более многочисленны названия физических свойств материалов и веществ, такие как kurczliwy, ściśliwy и под.

\footnotetext{
${ }^{22}$ См. Narodowy Korpus Języka Polskiego, [в:] электронный ресурс: http://nkjp.pl/ poliqarp/nkjp300/query/ (11.02.2015).
} 
